\title{
IMPROVING STUDENTS' SPEAKING SKILL BY USING PICTURE STRIP STORY
}

\author{
Odi Kosdian \\ Department of English Education, University of Kuningan \\ Email: odikosdian@yahoo.com
}

APA Citation: Kosdian, O. (2016). Improving students' speaking skill by using picture strip story. Indonesian EFL Journal, 2(2), 100-109

Published: 01-07-2016

\begin{abstract}
This research is aimed at improving students' speaking skill by using picture strip story in class XI IPA 1 of Senior High School 1 Luragung. The problems in this research are the low of students' skill in speaking. This research was applied through collaborative action research which was conducted in two cycles. The subject of this research was English subject in class XI IPA I with total number of students 34. The result of the research showed that picture strip story could improve students' speaking skill. The result of test I was 62.69 , test II was 68.83 and test III was 74.22. The students who passed the Minimum Mastery Criterion (KKM) were 22 students or $64.71 \%$. In addition, the result of field notes showed that the classroom situation during teaching learning process by using picture strip story created the positive atmosphere. In cycle 1 , there were no students who chatted and played handphone during the teaching and learning process by using picture strip story, all of students in a group did the task together and discussed it each other, the students could answer teacher's question, and all of students spoke in English while expressing their ideas. In cycle 2, the classroom situations were completed with students asking questions to the teacher.
\end{abstract}

Keywords: speaking skill, picture strip story, improve, collaborative action research

\section{INTRODUCTION}

Speaking is the most important skill of all the four simplex skills. According to Sarosdy, Bencze, Poor and Vadnay (2006, p.57), "of all the four simplex skills (listening, reading, speaking, writing) speaking seems to be the most important as people who know a language are referred to as 'speakers' of that language, as if speaking included all other kinds of knowing a language." It means that speaking is important as standard of mastering language include for students in language class.

Then, for students in Indonesia as EFL learners, speaking also is the most important skill. Based on the KTSP academic curriculum, Agus, Mahrum, and Hastini (2014, p. 2) explain that "the goal of language learning is to enable students to communicate the language." The main purpose of learning is aimed to improve the students' skill in communicating
English well. Furthermore, the students should master all of the speaking components; those are fluency, accuracy, and comprehensibility. On the other hand, Richards \& Renandya (2002, p. 121) states that "a large percentage of the world's language learners study English in order to develop proficiency in speaking." Then, Riggenback \& Lazaraton as cited in Cahyono \& Widiati (2006) tell that "students of second/foreign language education programs are considered successful if they can communicate effectively in the language." Here, in English learning, speaking is a main purpose for student. So, they are considered successful if they can communicate well in English. As EFL learners, they should master speaking skill to be successful.

Opposite with it, the students of SMAN 1 Luragung in XI IPA 1 class, they 


\section{Odi Kosdian}

Improving Students' Speaking Skill by Using Picture Strip Story

face speaking skill problems. The first, the students have problems in fluency; they have too long time for pausing and they have many hesitation or filler. The second, they have problems in pronunciation; there are many phonemes errors in articulations of vowels and consonants, also there are question intonation errors. The third, they have grammatical errors; there are tenses errors of present tense and past tense, also there are error sentence grammars of question. The fourth, they have the limitation of vocabulary knowledge; there are too much code mixing and register errors. And the last, they also have comprehension problem; they can't answer simple question about their story telling.

Moreover, in English learning there are other students' activities. First, some students chat with his/her classmate during the teacher was explaining in front of the class. Second, the students were busy using hand phone during teacher explaining material. Third, only the leader of group who did the task well in the class, the others chat. Fourth, there was no feedback from students towards teacher's question. Fifth, there was no student who tried to express their idea in English and then, there was no question to the teacher.

From the problems above, the researcher collaborated with the teachers and lecturers. The teachers were Mrs. Pristie Antari S.Pd and Mrs. Ria Shofariatin S.Pd, who teach in Senior High School 1 Luragung. Then, the lecturers were Mr. Yayan Suryana M.Pd and Mr. M. Aprianto B.N. M.Pd from Kuningan University. Finally, we took Communicative Language Teaching (CLT) approach to improve students' speaking skill. The purpose of CLT based on Diane Larsen-Freeman (2000, p. 128), "the goal is to enable students to communicate in the target language." So, CLT was appropriate approach to improve students' speaking skill. Then, because of CLT has some techniques, the researcher chose one technique. According to Freeman (2000, p. 132), "there are some materials and techniques associated with CLT, they are authentic materials, scrambled sentences, language games, picture strip story, and role play." So, the researcher chose picture strip story technique to improve students' speaking skill.

The researcher considered the using of picture strip story because there are some supporting statements from many scientists who explain the correlation between picture and speaking skill. One of them, for example, is Andrew Wright (2004, p. 17), who says that "speaking and writing are both productive skills and pictures can often be used in similar ways to promote them." So, it strengthens to use picture strip story to be assosiated with CLT for improving students' speaking skill. Besides that, picture strip story also can overcome classroom situation's problem above. Based on Canning-Wilson as cited in Nurvitasari (2014) stated that the picture is one of media, which can help teacher draws students' interest and improves students' motivation to learn because pictures assist students develop creativity and increase thinking ability. Moreover, according to Wright (2004, p. 71), "the picture strips devised especially for language teaching are usually very boring. Alternative sources are cartoon strips or photo story strips." So, it means that picture strip story appropriates to overcome some classroom situation's problems in SMAN 1 Luragung.

\section{METHOD}

In this study, the researcher took Action Research (AR), especially collaborative action research. Carr \& Kemmis as cited in Burns (2010) gave the definition of action research as follows: 
'self-reflective enquiry' undertaken by participants in order to improve the rationality and justice of their own social or educational practices as well as their understanding of these practices and the situations in which these practices are carried out.

Besides, according to Ferrance (2000, p. 1), "action research is a process in which participants examine their own educational practice systematically and carefully, using the techniques of research." Moreover, based on Fraenkell \& Wallen (2009, p. 589) stated that "action research is conducted by one or more individuals or groups for the purpose of solving a problem or obtaining information in order to inform local practice." Also, Carmen as cited in Burns (2010) said that "AR is a reflective process that aims to solve a particular teaching-learning problem that has been identified." Meanwhile, Elliot as cited in Burns (2010) said that "CAR is the study of a social situation with the view to improving the quality of the action in it." So, action research is a research which is conducted by teachers in the classroom to improve the quality or to solve the problem in teaching learning process based on theory or experience or a hypothesis they think of an intervention.

In this study, the researcher used collaborative action research. Based on Ferrance $(2000$, p. 6$)$ that "some kinds of action research, they are: individual teacher research, collaborative action research, school wide action research, and district wide action research. Then, based on explanation above, the researcher involves two teachers from school and two lecturers from university in doing this collaborative action research. Then, Ferrance (2000) gave specific explanation about collaborative action research:

Collaborative action research may include as few as two teachers or a group of several teachers and others interested in addressing a classroom or department issue. This issue may involve one classroom or a common problem shared by many classrooms (p. 4).

The model of Collaborative Action Research as one kind of AR that the researcher used was Spiral Model by Kemmis and McTaggart. Based on Kemmis \& McTaggart as cited in Burns (2010) that "who are major authors in this field, AR typically involves four broad phases in a cycle of research." They proposed a spiral model comprising four steps: planning, acting, observing and reflecting.

\section{Planning}

According to Kemmis and McTaggart as cited in Burns (2010), they say:

In this phase, we identify a problem or issue and develop a plan of action in order to bring about improvements in a specific area of the research context. This is a forward-looking phase where we consider: a) what kind of investigation is possible within the realities and constraints of our teaching situation; b) what potential improvement we think possible.

Besides, Ferrance (2000, p. 3) says, "a plan of research can involve a single teacher investigating an issue in his or her classroom, a group of teachers working on a common problem, or a team of teachers and others focusing on a school- or district-wide issue."

Based on explanations above, in this phase, the researcher identifies the problems in the classroom with the teacher. Then, we discuss this problem with other teacher to decide what appropriate solution is to overcome this problem. Next, one is involved as outside supporter from community partner.

\section{Action}

Kemmis and McTaggart as cited in Burns (2010), they state: 
Odi Kosdian

Improving Students' Speaking Skill by Using Picture Strip Story

The plan is carefully considered one which involves some deliberate interventions into our teaching situation that we put into action over an agreed period of time. The interventions are critically informed as we question our assumptions about the current situation and plan new and alternative ways of doing things.

Based on explanation above, the researcher put the plan into action. The researcher applied the lesson plan into action in the class. It meant that in this phase, the teacher taught students by using CLT approach, especially picture strip story technique.

\section{Observation}

The researcher in observation phase took participant observation, where the researcher also participated in this step as the teacher. According to Fraenkell and Wallen (2009, p. 441), that "in participant observation studies, researchers actually participate in the situation or setting they are observing." Besides, Kemmis and McTaggart as cited in Burns (2010), they tell:

This phase involves in observing systematically the effects of the action and documenting the context, action, and opinions of those involved. It is a data collection phase where we use open-eyed and open minded tools to collect information about what is happening.

Based on statement above, the researcher collected information about what is happening when picture strip story technique was applied by documenting context and action. Besides, the researcher noted all of case which happen during observes that was needed carefully.

\section{Reflection}

Kemmis and McTaggart as cited in Burns (2010) describe:

At this point, we reflect on, evaluate and describe the effects of the action in order to make sense of what has happened and to understand the issue we have explored more clearly. We may decide to do further cycles of action research to improve the situation even more, or to share the story of your research with others as part of your ongoing professional development.

Based on explanation above, the researcher reflected, evaluated, and described the result in each cycle. The result from the cycle was evaluated to make the next cycle be better in improving students' speaking skill. Then, the researcher also shared the story of the research with others as part of the professional development.

Figure 1. Cyclical AR model based on Kemmis and McTaggart

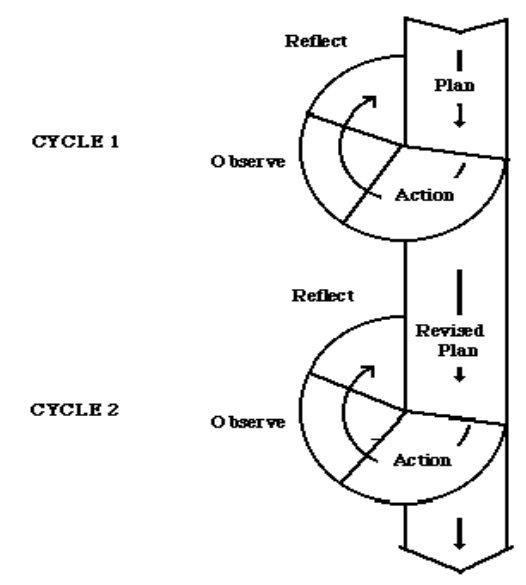

Cyclical AR model based on Kemmis and McTaggart (as cited in Burns, 2010) 
RESULTS AND DISCUSSION The Interpretation of Interview after Action Research

Interview was conducted after action research on Saturday, $31^{\text {th }}$ October 2015. The researcher and collaborators carried out the interview started 10.00 A.M. and finished at 10.30 A.M. The first criterion talked about general condition in speaking class during implementing the action. It was found that students' condition were better rather than before. In this sense, the most of students listened to the teacher's explanation. It meant that students didn't chat and play hand phone again during teacher explained the material. Then, every student in a group did the task together and discuss it each other. Moreover, most of them could answer teacher's question correctly. It meant that students gave feedback to the teacher. Besides, every student expressed their idea through pictures orally, so every student spoke in English one by one. The last, students gave question to the teacher when they didn't understand.

The second criterion talked about students' speaking skill. The researcher and collaborators decided that picture strip story could improve students' speaking skill. Based on the result of test 1 , test 2 , and test 3 , it can be seen that students' speaking skills were improving. The first, the mean of fluency improved from 63.73 in test 1 become 70.02 in test 2 , and 75.98 in test 3 . The second, pronunciation improved from 64.36 in test 1 become 68.31 in test 2 , and 73.56 in test 3 . The third, grammar improved from 61.52 in test 1 become 66.96 in test 2 , and 71.72 in test 3 . The fourth, vocabulary improved from 63.09 in test 1 become 69.59 in test 2 , and 75.43 in test 3 . The last, comprehension improved from 60.74 in test 1 become 69.28 in test 2 , and 74.43 in test 3 . Then, from mean score of speaking from test 1 to test 3 increased that was from 62.69 to 74.22 .

The third criterion talked about the difficulties in implementing picture strip story. Every weakness could be overcome in every cycle. So, there was no big problem during implementing picture strip story in the class. But, there was one weakness; the weakness of the last cycle is reference of picture strip story in cycle 2 only used one source. Actually, be better if use many sources such as in cycle 1 . But, this case didn't have big influence towards the effectiveness of picture strip story in improving students' speaking skill.

The last, was about collaborator's opinion toward picture strip story. The collaborators said that picture strip story was a good technique in teaching speaking. They were interested and motivated to use it for improving students' speaking skill.

Figure 2. The Improvement of Students' Speaking Score

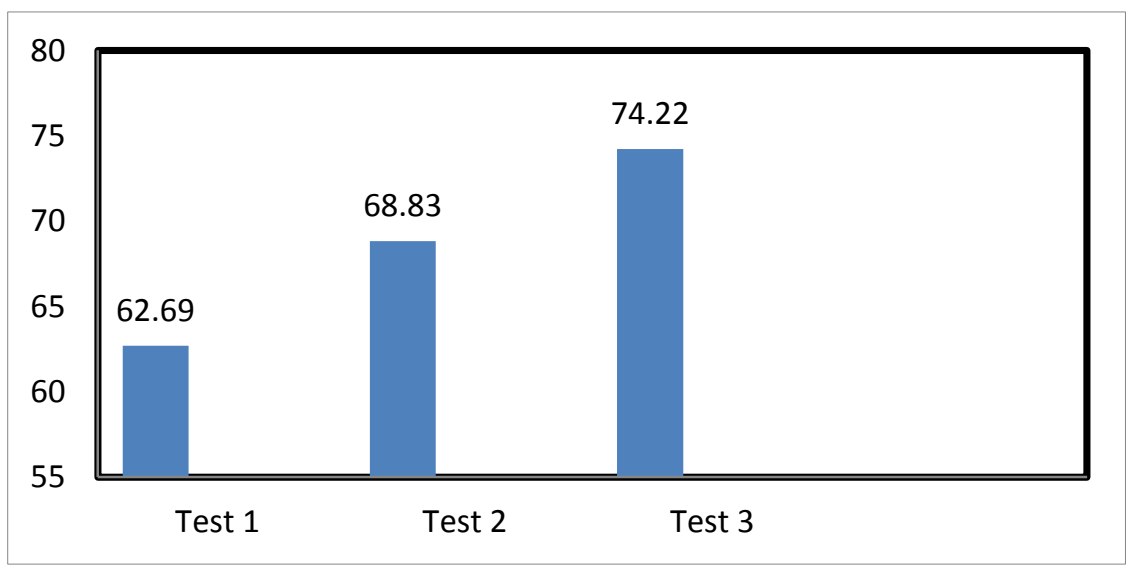


Odi Kosdian

Improving Students' Speaking Skill by Using Picture Strip Story

From the result above, it showed that there was improvement of students' speaking score. From test 1, the mean of speaking score was 62.69 improved to
68.83 in test 2 and 74.22 in test 3 . It indicated that there was an improvement of students' speaking skill from test 1 to test 3 through picture strip story.

Figure 3. The Improvement of Speaking Skill's score

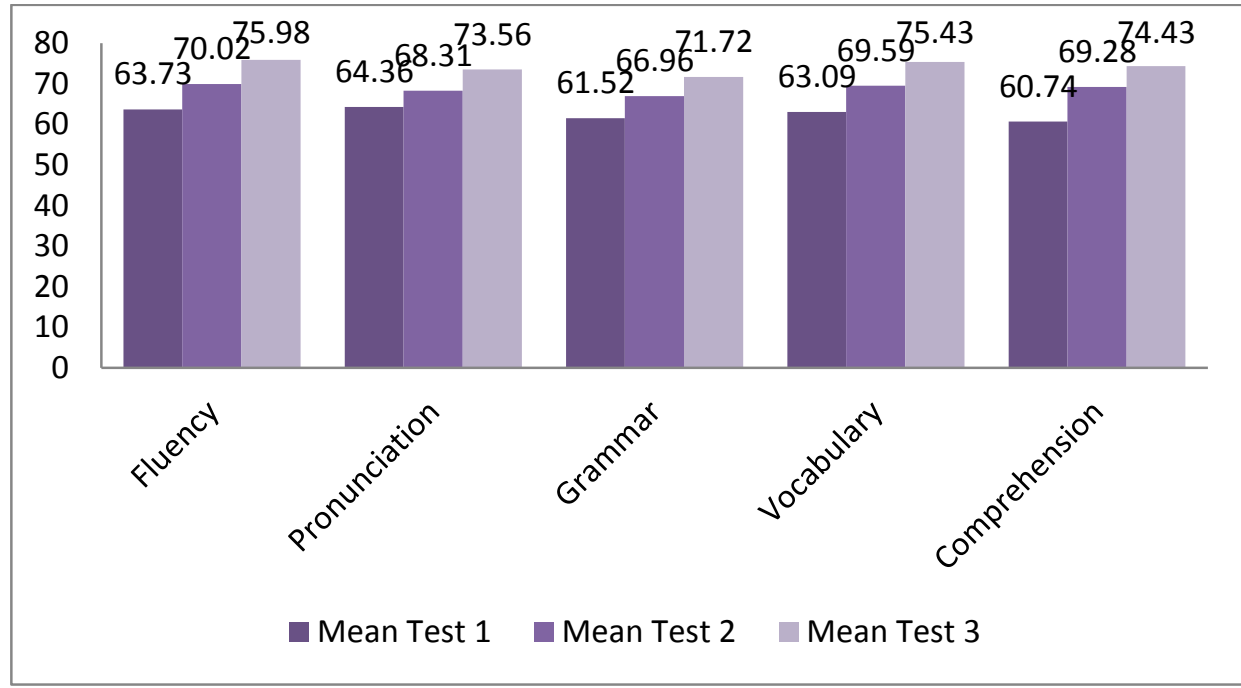

Based on the result above, it can conclude that students' speaking skills were improving. First, the mean of fluency improved from 63.73 in test 1 to 70.02 in test 2 , and 75.98 in test 3. Second, pronunciation improved from 64.36 in test 1 to 68.31 in test 2 , and 73.56 in test 3 . Third, grammar improved from 61.52 in test 1 to 66.96 in test 2 , and 71.72 in test 3 . Fourth, vocabulary improved from 63.09 in test 1 to 69.59 in test 2 , and 75.43 in test 3 . The last, comprehension improved from 60.74 in test 1 to 69.28 in test 2 , and 74.43 in test 3 . Then, from mean score of speaking from test 1 to test 3 increased that was from 62.69 to 74.22 . It indicated that there was an improvement in students' speaking skill from test 1 to test 3 through picture strip story.

Figure 4. The Improvement of Speaking Graduation

\begin{tabular}{|c|c|c|c|}
\hline $70.00 \%$ & \multirow{7}{*}{$17.65 \%$} & \multirow{7}{*}{$38.24 \%$} & $64.71 \%$ \\
\hline $60.00 \%$ & & & \\
\hline $50.00 \%$ & & & \\
\hline $40.00 \%$ & & & \\
\hline $30.00 \%$ & & & \\
\hline $20.00 \%$ & & & \\
\hline $10.00 \%$ & & & \\
\hline $0.00 \%$ & $\begin{array}{c}\text { Test } 1 \\
\text { Graduation (6 } \\
\text { students) }\end{array}$ & $\begin{array}{c}\text { Test } 2 \\
\text { Graduation (13 } \\
\text { students) }\end{array}$ & $\begin{array}{c}\text { Test } 3 \\
\text { Graduation (22 } \\
\text { students) }\end{array}$ \\
\hline
\end{tabular}


From the result above, it showed that there was improvement of students' speaking skill, seeing the number of students who graduated from the KKM. There was 22 student (64.71\%) could pass the KKM, whereas before in test 2 only 13 students (38.24\%), moreover in test 1 only 6 students (17.65\%). It meant that the target was achieved because more than $50 \%$ that was $64.71 \%$ students passed KKM.

Table 1. The Improvement of Classroom Situation

\begin{tabular}{|c|c|c|c|c|c|}
\hline \multirow{2}{*}{ No } & \multirow{2}{*}{$\begin{array}{l}\text { Problem } \\
\text { Observed }\end{array}$} & \multicolumn{3}{|c|}{ Indicator } & \multirow{2}{*}{ Success } \\
\hline & & Preliminary & Cycle 1 & Cycle 2 & \\
\hline \multirow[t]{2}{*}{1} & \multirow[t]{2}{*}{$\begin{array}{l}\text { The } \\
\text { students } \\
\text { couldn't } \\
\text { focus. }\end{array}$} & $\begin{array}{l}\text { a. They chatted with } \\
\text { his/her classmate during } \\
\text { the teacher was } \\
\text { explaining in front of the } \\
\text { class. }\end{array}$ & $\begin{array}{l}\text { a. All students didn't } \\
\text { chat again during the } \\
\text { teacher was explaining } \\
\text { in front of the class. }\end{array}$ & $\begin{array}{l}\text { a. All students didn't chat } \\
\text { during the teacher was } \\
\text { explaining in front of the } \\
\text { class. }\end{array}$ & $\sqrt{ }$ \\
\hline & & $\begin{array}{l}\text { b. They were busy using } \\
\text { hand phone during } \\
\text { teacher explaining } \\
\text { material. }\end{array}$ & $\begin{array}{l}\text { b. All students didn't use } \\
\text { hand phone again } \\
\text { during the class. }\end{array}$ & $\begin{array}{l}\text { b. All students didn't use } \\
\text { hand phone during the } \\
\text { class. }\end{array}$ & $\sqrt{ }$ \\
\hline \multirow[t]{5}{*}{2} & \multirow[t]{5}{*}{$\begin{array}{l}\text { They were } \\
\text { passive }\end{array}$} & $\begin{array}{l}\text { a. Only the leader of group } \\
\text { who did the task well in } \\
\text { the class, the others chat. }\end{array}$ & $\begin{array}{l}\text { a. All students in a group } \\
\text { did the task together } \\
\text { and discuss it each } \\
\text { other. }\end{array}$ & $\begin{array}{l}\text { a. All students in a group did } \\
\text { the task together and } \\
\text { discuss it each other. }\end{array}$ & $\sqrt{ }$ \\
\hline & & $\begin{array}{l}\text { b. There was no feedback } \\
\text { from students towards } \\
\text { teacher question }\end{array}$ & $\begin{array}{l}\text { b. There was feedback } \\
\text { from students. } \\
\text { Students could answer } \\
\text { teacher's question. }\end{array}$ & $\begin{array}{l}\text { b. There was feedback from } \\
\text { students. Students could } \\
\text { answer } \\
\text { question. }\end{array}$ & $\sqrt{ }$ \\
\hline & & $\begin{array}{l}\text { c. There was no student } \\
\text { who tried to express } \\
\text { their idea in English. }\end{array}$ & $\begin{array}{l}\text { c. All students expressed } \\
\text { their idea in English } \\
\text { through pictures. }\end{array}$ & $\begin{array}{l}\text { c. All students expressed } \\
\text { their idea in English } \\
\text { through pictures. }\end{array}$ & $\sqrt{ }$ \\
\hline & & $\begin{array}{l}\text { d. There was no question to } \\
\text { the teacher. }\end{array}$ & $\begin{array}{l}\text { d. There still no question } \\
\text { to the teacher. }\end{array}$ & $\begin{array}{l}\text { e. Many students gave } \\
\text { questions to the teacher }\end{array}$ & $\sqrt{ }$ \\
\hline & & d. There was no speaking & $\begin{array}{l}\text { f. All students speak in } \\
\text { English by express } \\
\text { their idea through } \\
\text { pictures. }\end{array}$ & $\begin{array}{l}\text { e. All studentsspeak in } \\
\text { English by express } \\
\text { his/her idea in English. }\end{array}$ & $\sqrt{ }$ \\
\hline
\end{tabular}

From the table above, it showed that the classroom situation in XI IPA 1 class was better than before. First, the most of students listened to the teacher's explanation. They didn't chat again and focus to the teacher. Whereas, before, they didn't listen to the teacher, whereas chatted with his/her classmate during the teacher was explaining in front of the class.
Second, they didn't use hand phone again during English class. Whereas, before in preliminary study situation, they didn't look at to the teacher, whereas they were busy to play hand phone during teacher explained the material.

Third, every student in a group did the task together and discusses it with each other. Whereas, before in 


\section{Odi Kosdian}

Improving Students' Speaking Skill by Using Picture Strip Story

preliminary study situation only the leader of group who did the task well in the class, the others chat.

Fourth, there was feedback from students. It can be seen when the researcher gave question to the students, most of them could answer correctly.

Fifth, every student expressed their idea through pictures. So, they could speak in English. Whereas, in preliminary study situation, there was no student who tried to express their idea in English. It meant that before hand, there was no speaking in the class during English class, but now through pictures strip story, they could express their idea in English orally.
Sixth, students asked to the teacher when they didn't understand. Whereas, in preliminary study and cycle 1 , they didn't give question to the teacher when they didn't understand the material during English class.

The last, every student spoke in English one by one. Whereas, in preliminary study they didn't speak in the class in English, starting from the opening until closing meeting in the English class.

So, all of classroom situations indicators got the target, so the researcher and collaborators decided that this action research is success.

Figure 5. Students' Responses toward Picture Strip Story (PSS)

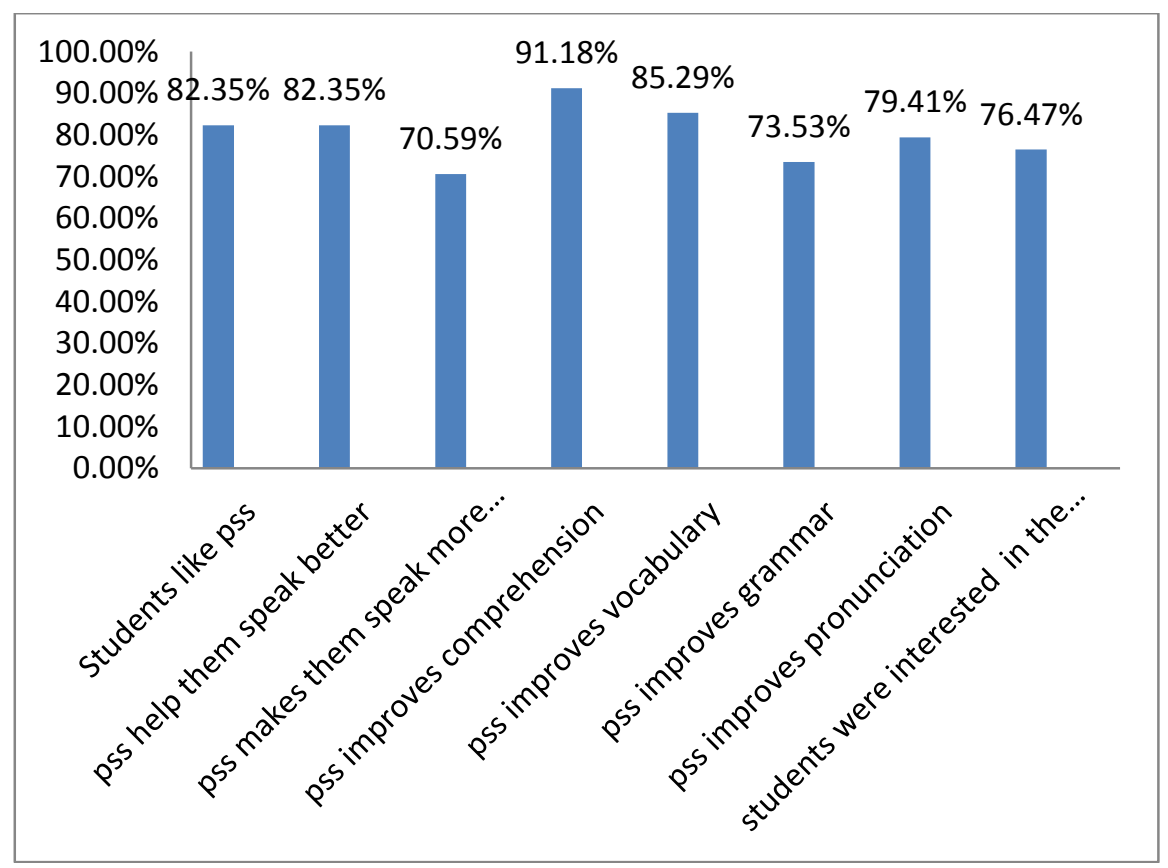

From the result of questionnaire above, it showed that students' response toward the picture strip story were positive. It could be proved by seeing the result of questionnaire. First, the result showed that 28 students (82.35\%) like picture strip story technique. Second, 28 students $(82.35 \%)$ felt that picture strip story helped them to speak better. Third, 24 students $(70.59 \%)$ assumed that picture strip story helped them to speak more fluently than before. Fourth, 31 students (91.18\%) felt more understand about the story with using picture strip story. Fifth, 29 students (85.29\%) felt that picture strip story could improve their vocabulary. Sixth, 25 students $(73.53 \%)$ felt that picture strip story could improve their grammar. Seventh, 27 students $(79.41 \%)$ felt that picture strip story could improve their grammar. The last, 26 students $(76.47 \%)$ were 
interested in the teaching way of the teacher. So, picture strip story not only improved students' speaking skill but also was liked by students.

\section{CONCLUSION}

Picture strip story can improve students' speaking skill. It can be proved by the result of test 2 and test 3 . First, the result of test 2 indicates the improvement of students' speaking skill. It describes the change of students' graduation of speaking in English subject are better than before; there are 13 students (38.24\%) can graduate from the KKM whereas before only 6 students (17.65\%). Second, the result of test 3 indicates significant improvement, there are 22 students (64.71\%) can pass KKM. So, it is more than $50 \%$. Besides, based on the result, the improvement can be seen from the increase of students' mean speaking score from 62.69 in the preliminary study and 68.83 at the first cycle to 74.22 in the second cycle. Then, picture strip story also makes classroom situations are controlled. It can be proved by seeing the acting phase of collaborative action research in cycle 2 and 3. First, in cycle 1 there are no students who chat and play hand phone again during teacher explain the material using picture strip story. Also, every student in a group does the task together and discusses it each other. Then, there are feedbacks from students. It can be seen when the researcher give question to the students, most of them can answer correctly. Moreover, every student expresses their idea through pictures. It makes no student who doesn't speak English in the class. Then, in cycle 2, the classroom situations are completed with students who give question to the teacher. So, picture strip story can overcome the problem of classroom situation at second grade in SMAN 1 Luragung. On the other hand, students' responses toward picture strip story activity in the class are positive. It can be proved by seeing the result of questionnaire which shows good response.

\section{REFERENCES}

Agus, I. P., Mahrum, M., \& Hastini. (2014). Improving speaking skill through information gap technique. Journal of English Language Teaching Society (ELTS), 2(4), 1-14. Retrieved from http://jurnal.untad.ac.id/jurnal/index. php/ELTS/article/view/3224/2295

Burns, A. (2010). Doing action research in English language teaching. New York: Routledge.

Canning-Wilson. (2001). Visuals \& language learning: Is there a connection.

Retrieved from www.eltnewsletter.com/back/Feb200 1/art482001.htm

Carr, W., \& Kemmis, S. (1986). Becoming critical: Knowing through action research. London: The Falmer Press.

Ferrance, E. (2000). Themes in education: Action research. Providence Rhode Island (RI): Brown University LAB.

Freeman, D. L. (2000). Techniques and principles in language teaching (2nd ed.). New York: Oxford University Press.

Kemmis, S., \& McTaggart, R. (Eds.). (1988). The action research planner (3rd ed.). Geelong: Deakin University Press.

Nurvitasari, H. (2014). Improving students' speaking ability by using picture: A classroom action research at the tenth grade students of SMA Negeri 3 Ketapang in the academic year 2013/2014. West Kalimantan Scholars: Studies on English Language and Education, 1(1), 18-37.

Richards, J. C. \& Renandya, W. A. (2002). Methodology in language teaching. New York: Cambridge University Press.

Sarosdy, J., Bencze, T. F., Poor, Z., \& Vadnay, M. (2006). Applied linguistics I for BA students in English. Budapest, Hungary: BölcsészKonzorcium.

Widiati, U., \& Cahyono, B. Y. (2006). The teaching of EFL speaking in the Indonesian context: The state of the art. BAHASA DAN SENI, 34(2), 269-292. Retrieved from 


\section{Odi Kosdian}

Improving Students' Speaking Skill by Using Picture Strip Story

http://sastra.um.ac.id/wp-

content/uploads/2009/10/The-

Teaching-of-EFL- Speaking-in-the Indonesian-Context-The-State-of-theArt-Utami-Widiati- Bambang-YudiCahyono.pdf.

Wright, A. (2004). Pictures for language learning. New York: Cambridge University Press. 